\title{
DÜBLIN
}

Technological University Dublin

ARROW@TU Dublin

\section{An Evaluation of a Community Dietetics Intervention on the Management of Malnutrition for Healthcare Professionals}

\author{
Sharon Kennelly \\ Technological University Dublin, Sharon.Kennelly@hse.ie \\ N. P. Kennedy \\ Trinity College Dublin \\ G. Flanaghan-Rughoobur \\ Health Services Executive Dublin Mid-Leinster
}

See next page for additional authors

Follow this and additional works at: https://arrow.tudublin.ie/schfsehart

Part of the Community Health and Preventive Medicine Commons, and the Environmental Public Health Commons

\section{Recommended Citation}

Kennelly, S. et al. (2010) An Evaluation of a Community Dietetics Intervetnion on the Managment for Healthcare Professionals. Journal of Human Nutrition and Dietetics, Vol.23 (6), 2010, pp.567.75. doi: 10.1111/j.1365-277X.2010.01111.x

This Article is brought to you for free and open access by the School of Food Science and Environmental Health at ARROW@TU Dublin. It has been accepted for inclusion in Articles by an authorized administrator of ARROW@TU

Dublin. For more information, please contact

arrow.admin@tudublin.ie, aisling.coyne@tudublin.ie, gerard.connolly@tudublin.ie.

Funder: Health Services Executive, Dublin, Ireland

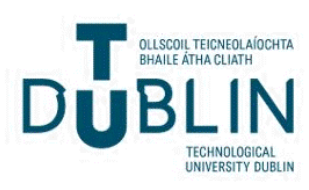




\section{Authors}

Sharon Kennelly, N. P. Kennedy, G. Flanaghan-Rughoobur, C. Glennon-Slattery, and Sheila Sugrue

This article is available at ARROW@TU Dublin: https://arrow.tudublin.ie/schfsehart/14 
This paper has been published in the Journal of Human Nutrition \& Dietetics 2010. 23(6):567-74. DOI: $10.1111 / \mathrm{j} .1365-277 X .2010 .01111 . X$. and is available with appendices at http://onlinelibrary. wiley.com

\section{RESEARCH PAPER}

\section{An evaluation of a community dietetics intervention on the management of malnutrition for healthcare professionals}

S. Kennelly* $\ddagger$, N. P. Kennedy†, G. Flanagan-Rughoobur, C. Glennon-Slattery* \& S. Sugrueł ${ }^{*}$ Community Nutrition \& Dietetics Service, Health Service Executive Dublin Mid-Leinster, Mullingar, Co. Westmeath, Ireland, $\ddagger$ Department of Biological Sciences, Dublin Institute of Technology, Dublin, Ireland, †Department of Clinical Medicine, Trinity College Dublin, Dublin, Ireland

Keywords: community nutrition, malnutrition, nutrition education programme, nutrition screening, oral sip feeds.

Correspondence:

S. Kennelly, Community Nutrition \& Dietetic

Department, HSE Dublin Mid-Leinster, Marlinstown Office Park Mullingar, Co.

Westmeath, Ireland.

Tel.: $+353(0) 449353220$

Fax: $+353(0) 449353228$

E-mail: sharon.kennelly@hse.ie

\section{Abstract}

Background: Healthcare professionals working in the community setting have limited knowledge of the evidence-based management of malnutrition. The present study aimed to evaluate a community dietetics intervention, which included an education programme for healthcare professionals in conjunction with the introduction of a community dietetics service for patients 'at risk' of malnutrition. Changes in nutritional knowledge and the reported management of malnourished patients were investigated and the acceptability of the intervention was explored.

Methods: An education programme, incorporating 'Malnutrition Universal 
Screening Tool (MUST)' training, was implemented in eight of 10 eligible primary care practices (14 general practitioners and nine practice nurses attended), in seven private nursing homes (20 staff nurses attended) and two health centres (53 community nurses attended) in conjunction with a community dietetics service for patients at risk of malnutrition. Nutritional knowledge was assessed before, immediately after and 6 months after the intervention using self-administered, multiple-choice questionnaires. Reported changes in practice and the acceptability of the education programme were considered using selfadministered questionnaires 6 months after the intervention.

Results: A significant increase in nutritional knowledge 6 months after the intervention was observed $(P<0.001)$. The management of malnutrition was reported to be improved, with $69 \%(38 / 55)$ of healthcare professionals reporting to weigh patients 'more frequently', whereas $80 \%$ (43/54) reported giving dietary advice to prevent or treat malnutrition. Eightypercent $(44 / 55)$ of healthcare professionals stated that 'MUST' was an acceptable nutrition screening tool.

Conclusion: An education programme supported by a community dietetics service for patients 'at risk' of malnutrition increased the nutritional knowledge and improved the reported management of malnourished patients in the community by healthcare professionals.

\section{Introduction}

Malnutrition is frequently under-recognised in the community setting (Elia et al., 2005). The importance of screening for malnutrition has been highlighted by expert groups [Malnutrition Advisory Group (MAG), 2003; National Institute for Health and Clinical Excellence (NICE), 2006; Volkert et al., 2006]. Malnutrition has many negative consequences that affect both the individual and the health service, such as delayed recovery from illness, poorer treatment outcomes, increased need for healthcare provision in the home, more frequent general practitioner (GP) visits, more hospital admissions, and longer hospital stays (MAG, 2003). It is recommended that nutrition screening should have multidisciplinary responsibility and that a consistent tool or criteria should be used by all healthcare professionals to identify malnutrition or risk of malnutrition (MAG, 2003). Expenditure on oral nutritional supplements (ONS), a commonly used treatment for malnutrition, has been growing steadily over the past number of years and was estimated to cost the Irish Health Service Executive (HSE) approximately €28 million in 2008 (Barry, 2009). In a recent study of ONS prescribing practices in the Irish community setting (Kennelly et al., 2009), approximately one-third of patients were 'unnecessarily' prescribed ONS. As a result of these findings, a community dietetics intervention that included a nutritional education programme for healthcare professionals and the instigation of a community dietetics service for patients 'at risk' of malnutrition was developed. Evidence from Irish and UK settings has shown that the management of malnutrition and the prescribing of ONS by healthcare professionals are largely not 'evidence-based' or in accordance with expert guidelines. Healthcare 
professionals receive little training on the management of malnutrition and access to literature on its management predominantly comes from sales representatives from companies selling clinical nutrition products (McCombie, 1999; Gale et al., 2001; Gall et al., 2001; Loane et al., 2004). Healthcare professionals working in the community setting have previously expressed an interest in improving their knowledge about the management of malnutrition and the appropriate prescribing of ONS (Loane et al., 2004), although the effectiveness and acceptability of methods to do so have not been established. However, the delivery of education programmes to healthcare professionals at their place of work, also known as 'education outreach' or 'academic detailing', has been shown to be effective in increasing the knowledge and improving the practice of healthcare professionals in other settings (Welschen et al., 2004; Madigan, 2005; Midlov et al., 2006).

The present study aimed to evaluate a dietetics intervention designed for healthcare professionals working in the community setting (i.e. GPs, practice nurses, community nurses and private nursing home staff nurses). Changes in knowledge resulting from the intervention, reported changes in practice related to the management of malnutrition and the acceptability of the education programme and resources used, including the 'Malnutrition Universal Screening Tool (MUST)' tool (MAG, 2003), were established.

\section{Materials and methods}

\section{Study setting}

The present study was carried out in 2006 and 2007, in one county in the midlands of the Republic of Ireland with a population of approximately 79000 people $(11 \%>65$ years of age) (Central Statistics Office, 2006) and 42 individual GPs registered with the HSE primary care unit. Ethical approval was received from the Dublin Institute of Technology and the HSE Dublin Mid-Leinster research ethics committees. Before commencement of the study, no GP practice, community nurse or private nursing home had access to an HSE-funded community dietetics service for patients 'at risk' of malnutrition.

Participants in community dietetics intervention Healthcare professionals were eligible to participate in the community dietetics education intervention if the primary care practice or private nursing home where they worked was involved in the earlier study that had investigated ONS prescribing practices (Kennelly et al., 2009). Participants included staff (GPs and practice nurses) from 10 primary care practices, staff nurses from seven private nursing homes and all community nurses $(n=53)$ working in the county where the study took place. 


\section{Community dietetics intervention}

\section{Content and format of the nutrition education programme}

An outline of the format and content of the education programme delivered to each health professional group is shown in Table 1. The format and content were developed after consultation with the health professional groups for whom the programme was designed and was based on previous Irish and UK studies on the nutritional knowledge and malnutrition management practices of community-based healthcare professionals (McCombie, 1999; Gall et al., 2001; Loane et al., 2004), clinical guidelines from expert bodies (NICE, 2006; Volkert et al., 2006) and current evidence for ONS use in the community setting (Stratton \& Elia, 2000; Milne et al., 2005).

The format and resources for the education programme were developed and tailored to each healthcare professional group (Table 1). One community dietitian (SK) facilitated each educational programme with support for practical group work from other community dietitians. The resources developed included a folder containing the theoretical content of the education programme (Table 1), case studies, and copies of two advice booklets for patients, 'Eating when you have a small appetite', which contained simple advice on how to achieve higher energy and protein intakes and 'A guide to using oral nutritional supplements', which contained advice on how to incorporate ONS into the diet. Both booklets were written specifically for this intervention. Each healthcare professional was also provided with a copy of 'MUST' (MAG, 2003).

\section{Community dietetics service for patients 'at risk' of malnutrition.}

Each primary care practice and private nursing home participating in the education programme was offered access to a new community dietetic referral service for patients 'at risk' of malnutrition. Healthcare professionals who attended the education intervention were encouraged to nutritionally screen patients using 'MUST' (MAG, 2003) and refer patients 'at risk' of malnutrition to the community dietetics service. It was also recommended that all patients with current ONS prescriptions, regardless of 'MUST' risk category, should be referred to the community dietitian for review.

\section{Evaluation of community dietetics intervention}

Evaluation of the nutrition education programme was carried out using the three selfadministered questionnaires described below; the timing of the administration of these questionnaires is shown in Fig. 1. A knowledge multiple choice questionnaire (MCQ) was used to evaluate changes in knowledge. MCQs have been recommended to assess changes in the knowledge of health professionals after educational programmes (Ghosh, 2008) and were administered at three time points (Fig. 1). The MCQ consisted of eight 
questions and evaluated the effectiveness of the education programme in delivering key learning points. Possible answers were modelled on the responses of healthcare professionals in previous studies (McCombie, 1999; Gall et al., 2001; Loane et al., 2004). Participants were required to add their initials to the MCQ to make them identifiable for statistical analysis. A question that determined any previous education or training healthcare professionals had received about ONS was also included when the questionnaire was first administered (i.e. before the intervention). The MCQ (Appendix S1) was pilot-tested with a mixed group of healthcare professionals prior to its use in the present study.

Reported practices relating to the management of malnutrition were investigated 6 months after the education programme using a self-administered questionnaire containing both open and closed questions (Appendix S2).

This evaluation included questions about the provision of simple dietary advice to patients 'at risk of malnutrition' and how ONS should be used. Healthcare professionals were also asked to report any difficulties they experienced in giving dietary advice to patients. The acceptability of the education programme itself was assessed using a self-administered questionnaire immediately after the delivery of the programme (Appendix S3).This questionnaire included questions on the format, content, and method of delivery of the education programme. This questionnaire was completed anonymously. The acceptability of the resources provided during the education programme to healthcare professionals including 'MUST' (MAG, 2003) was determined as part of the self-administered questionnaire 6 months after the intervention (Appendix S2).

Six months after the introduction of the community dietetics service for patients 'at risk' of malnutrition, referral forms received via the new referral pathway based on 'MUST' (MAG, 2003) were reviewed (by SK) to determine the number and source of referrals and to establish the location where patients were reviewed by the community nutrition and dietetics service.

\section{Statistical analysis}

Data were entered into spss for Windows, version 15 (SPSS Inc., Chicago, IL, USA) database and then analysed. The Friedman test was used to determine if nutritional knowledge was significantly different across the three time periods (before, immediately after and 6 months after the intervention programme). Wilcoxon signed rank tests were used to identify differences in nutritional knowledge from before the education programme to immediately after it was delivered, and from before the programme to 6 months after its delivery.

\section{Results}

\section{Participation in nutrition education programme and evaluation of intervention.}

A total of 96 (10 male and 86 female) healthcare professionals participated in the education programme(Table 1). These healthcare professionals reported working in the community 
setting for an mean (SD) of 11.9 (8.87) years. The percentage completing the evaluation questionnaires at each time point is shown in Fig. 1. Reasons for non-completion of questionnaires immediately before or after the education programme were late arrival $(9 / 96)$ or early departure (5/96) as a result of clinical workload. Reasons for non-completion of questionnaires 6 months after the education programme included not wishing to complete (5/96), no longer working in the position (20/96), on annual leave during the study period (5/96) and uncontactable (11/96).

\section{Participants' previous education on ONS}

Forty-one of 96 (43\%) healthcare professionals reported receiving previous education or training on ONS. Thirty seven healthcare professionals from this group gave further detail about the type of education or training they had received: 'Visits from sales representatives' was the most frequently reported response (33/37, 89\%), with 'attending study days' reported by a small number $(4 / 37)$.

\section{Evaluation of changes in nutritional knowledge}

Nutritional knowledge at all three time points (i.e. before, immediately after, and 6 months after the intervention) was assessed in 54\% (52/96) of healthcare professionals who participated in the education programme. Table 2 shows the differences in mean knowledge scores during the three time periods for GPs, nurses and the full group

$(n=52)$. There was a significant improvement in the mean knowledge score across the three time periods ( $\mathrm{v} 2=68.7, \mathrm{P}<0.05$ ) for the full group. When nutritional knowledge at specific time points was tested, a significant increase occurred from baseline (pre-intervention) to immediately after the education programme $(z=) 7.625, P<0.001)$ and from baseline to 6 months after the dietetics intervention $(z=) 5.535, P<0.001)$.

\section{Reported malnutrition management practices 6 months after the community dietetics intervention}

Reported practices related to the management of malnutrition by healthcare professionals 6 months after the dietetics intervention are shown in Table 3 . The majority of healthcare professionals $(80 \% ; n=43$ ) reported always providing dietary advice to patients. The type of dietary advice most frequently stated as provided included the provision of dietary advice to patients using the information contained in the 'small appetite patient advice booklet' $(n=20)$. Other dietary advice offered included eating small, frequent meals $(n=11)$ and fortification of food $(n=9)$. Difficulties reported by healthcare professionals in providing patients with dietary advice included 'lack of co-operation from patients' $(n=12)$, 'social factors' $(n=12)$, and 'lack of time' $(n=8)$. 'Patients living alone with poor support' $(n=7)$, 'dementia/cognitive decline' $(n=6)$ and 'clinical depression' $(n=6)$ also presented difficulty for healthcare professionals when providing dietary advice. After the community dietetics intervention, consultation with the dietitian was the most common factor reported to influence 
the prescribing of ONS $(n=14)$. Low body mass index (BMI) or a BMI below $20 \mathrm{~kg} \mathrm{~m}-2(\mathrm{n}=$ 13), unintentional weight loss ( $n=10)$, the use of 'MUST' $(n=9)$ and poor appetite/dietary intake $(n=8)$ also influenced the decision to prescribe or recommend ONS. Advice provided specifically about ONS included 'not using ONS as a meal replacement' $(n=7)$. Recommendations on the volume $(n=5)$ and timing of ONS $(n=5)$ were also provided after the dietetics intervention. Measurement of body weight $(n=12)$ was the most commonly reported practice for monitoring patients prescribed ONS. Six months after the dietetics service for patients 'at risk' of malnutrition had been initiated at the eight primary care practices who participated in the intervention, 90 patients had been reviewed by the community dietitian. The majority of referrals (42\%; 38/90) were made by a GP, $22 \%$ (20/90) by community nurses, $14 \%$ (12/90) by staff nurses in nursing homes, $12 \%(11 / 90)$ by practice nurses, and $10 \%$ (9/90) by dietitians in acute hospitals in the geographical area. The largest number of patients referred were seen in the GP practice $(n=36 ; 40 \%)$ although one-third ( $n$ $=31 ; 34 \%)$ were seen on a domiciliary visit and one-quarter $(n=23 ; 26 \%)$ were seen in the private nursing home in which they resided.

\section{Acceptability of the nutrition education programme}

All (73/73) healthcare professionals who answered the question reported that the format and content of the nutrition education programme was useful. Eighty-nine percent (81/91) gave comments on the 'most useful' aspects of the education intervention, which included: 'case studies' ( $n=16)$, 'underlying causes of malnutrition' $(n=12)$ and 'appropriate use of ONS'. The majority (70/91, 77\%) were 'satisfied' with the duration of the education intervention, although five would have liked it to be longer, including three community nurses and two nursing home staff nurses. Six healthcare professionals suggested that the intervention could be improved by the inclusion of more case studies. Six months after the intervention, $80 \%$ of healthcare professionals (44/55) agreed that 'MUST' is an 'acceptable' nutrition screening tool to use in their workplace, with $62 \%$ (34/55) rating it as 'easy' or 'very easy' to use. This included 10/10 GPs, 27/34 community nurses, three of five practice nurses and four of six nursing home staff nurses. The reported use of 'MUST' by healthcare professionals since the education programme is shown in Table 3. A mean rating in the range 4.1-4.6 out of 5 was given to the resources developed for the intervention by the participating healthcare professionals.

\section{Discussion}

Improving the management of malnutrition in the community presents a challenge for the health services and community dietitians. The evaluation of this community dietetics intervention suggests that this type of intervention has beneficial effects on nutritional knowledge results in an improvement in the management of malnutrition, prescription of ONS and monitoring of patients prescribed ONS in the community setting and is acceptable to healthcare professionals. Nutritional knowledge increased in both GPs and nurses after the 
education programme and this increase in knowledge appeared to be retained when healthcare professionals were followed up 6 months later. This is in keeping with the findings of other studies that have also reported improvements in nutritional knowledge and practices using this type of education intervention (Cadman \& Findlay, 1998; Gall et al., 2001; Madigan, 2005)

The majority of healthcare professionals (both GPs and nurses) surveyed 6 months after the intervention reported having made positive changes to their practice in managing malnutrition, including weighing patients 'more frequently', providing simple dietary advice to patients 'at risk' of malnutrition and using clinically justifiable reasons to prescribe or recommend ONS. The results of the present study suggest that the management pathway for patients at risk of malnutrition developed by the MAG of the British Association for Parenteral and Enteral Nutrition (MAG, 2003) works well as an onward referral tool to the community dietetic service for patients who are malnourished or 'at risk' of malnutrition in the community setting.

After the intervention, the present study contrasts favourably with two previous studies carried out in the same geographical region (Loane et al., 2004; Kennelly et al., 2009), both of which show little evidence of nutritional assessment techniques such as weighing patients or the provision of simple dietary advice to patients prescribed ONS. This suggests that there has been a 'shift' towards more 'evidence-based' practice by healthcare professionals in the region brought about by the intervention. The acceptability of the nutritional education programme was found to be good because healthcare professionals reported high satisfaction ratings with the format and content of the education programme. Providing targeted education programmes for healthcare professionals within their workplace has previously been reported to be acceptable in other studies involving healthcare professionals (O'Brien et al., 2007).

The healthcare professionals involved in this intervention highly rated the 'MUST' (MAG, 2003). The majority found the 'MUST' to be 'user-friendly' and an acceptable nutrition screening tool; this is in keeping with the findings of a previous study by Stratton et al. (2004) in which the screening tool was also found to be 'easy to use' by healthcare professionals. Although a small number of healthcare professionals reported not using 'MUST' 6 months after the education programme, a possible explanation may be that these healthcare professionals may not have encountered patients who were 'at risk' of malnutrition on a regular basis; for example, some community and practice nurses commented that the majority of their daily work was in the area of child health. With GPs, it was apparent that, in some cases, the task of nutritional screening was delegated to another healthcare professional.

The most common difficulties in providing dietary advice for 'malnourished' patients or those 'at risk' of malnutrition in this study were reported to be 'poor patient co-operation' and 'lack of time'. These two factors have been identified in other studies investigating low professionals (Kushner, 1995; Hiddink et al., 1999; Moore \& Adamson, 2002). It was not possible to determine the reasons for 'lack of patient co-operation' reported by the 
participants in the present study but it could be speculated that it may be related to factors such as dementia, depression, or poor social circumstances, which have been reported in other studies (Browne et al., 1997; Gall et al., 2001; Kennelly et al., 2009).

Although this evaluation demonstrates that changes in practices in relation to the management of malnutrition in the community are achievable when healthcare professionals receive a specifically designed education programme coupled with access to dietetics services, some limitations of the present study must be noted. The sample of GP practices involved was relatively small $(n=8)$ and some of the findings observed in the study may not therefore be observed in evaluations of similar education programmes elsewhere. A further challenge encountered in carrying out the evaluation was that there was a relatively high turnover of nursing staff in all settings, although this was particularly the case in nursing homes, which meant that there was a reduction in the number of nurses who completed the evaluation questionnaires 6 months after the intervention. The high turnover of staff suggests that frequent and repeated education programmes are required to maintain high levels of nutritional knowledge, which has considerable implications for manpower planning for community dietetics services as the providers of such training. Recently, the use of a 'trainthe-trainer' method for educating nursing home staff in the use of 'MUST' was reported as successful (Lee \& Scott, 2009); this may offer a possible solution to training needs in the nursing home setting.

The findings of the present study suggest that a community dietetics intervention comprised of an education programme supported by a community dietetics service for patients 'at risk' of malnutrition increased the nutritional knowledge and improved the reported management of malnourished patients in the community by healthcare professionals. Evaluation of the actual changes in ONS prescribing practices by auditing patient medical records and the HSE database of ONS prescriptions is required to further verify the effects of this community dietetics intervention.

\section{Acknowledgments}

The authors would like to thank the healthcare professionals who took part in this study. The authors would also like to thank Dr Clare Corish of the Department of Biological Sciences, Dublin Institute of Technology, Dublin, Ireland, who is academic supervisor of SK for her help. 
Table 1: Outline description of the education interventions delivered to each health professional group.

\begin{tabular}{|c|c|c|c|c|}
\hline $\begin{array}{l}\text { Health } \\
\text { Professional \&( } \\
\text { Size of Group) }\end{array}$ & $\begin{array}{l}\text { Length of } \\
\text { Session }\end{array}$ & Location & Format & Summary of Content \\
\hline $\begin{array}{l}\text { General } \\
\text { Practitioners } \\
\text { \& Practice } \\
\text { Nurses } \\
\text { (Size : } 1-5 \text { per } \\
\text { group ) }\end{array}$ & $\begin{array}{l}\text { Lunchtime } \\
45 \text { mins } \\
-1 \text { hour }\end{array}$ & $\begin{array}{l}\text { On site } \\
\text { at GP } \\
\text { practice }\end{array}$ & $\begin{array}{l}\text { PowerPoint } \\
\text { Presentation } \\
\text { Case study }\end{array}$ & $\begin{array}{l}\square \text { Underlying Causes of } \\
\text { Malnutrition } \\
\square \text { Patient groups at risk of } \\
\text { malnutrition } \\
\square \text { Evidence-Based Use of ONS } \\
\square \text { Basic Dietary Advice } \\
\square \text { MUST Screening tool } \\
\square \text { Case study }\end{array}$ \\
\hline $\begin{array}{l}\text { Nursing Home } \\
\text { Staff } \\
\text { Nurses } \\
\text { Size : }(1-6 \text { per } \\
\text { group) }\end{array}$ & $\begin{array}{l}\text { Afternoon } \\
\text { Approx } 1 \\
\text { and } 1 / 2 \\
\text { hours }\end{array}$ & $\begin{array}{l}\text { On site at } \\
\text { nursing } \\
\text { home }\end{array}$ & $\begin{array}{l}\text { Power point } \\
\text { presentation } \\
\text { Case studies }\end{array}$ & $\begin{array}{l}1 \text { hour Theory, as for GPs/ } \\
\text { practice nurses, plus } 1 / 2 \text { hour } \\
\text { practical } 2 \text { case studies } \\
\text { worked through with answers }\end{array}$ \\
\hline $\begin{array}{l}\text { Public Health } \\
\text { Nurses } \\
\text { (10-15 per } \\
\text { group) }\end{array}$ & $\begin{array}{l}\text { Afternoon } \\
3 \text { hours with } \\
15 \text { mins } \\
\text { break } \\
\text { halfway } \\
\text { through: } \\
75 \text { mins } \\
\text { theory, } \\
90 \text { mins } \\
\text { practical } \\
\text { content. }\end{array}$ & $\begin{array}{l}\text { Local } \\
\text { Health } \\
\text { Centres }\end{array}$ & $\begin{array}{l}\text { Power-point } \\
\text { presentation } \\
\text { Case studies }\end{array}$ & $\begin{array}{l}\square \text { Theory as for GPs, practice } \\
\text { nurses with greater discussion } \\
\text { around dietary advice, meal } \\
\text { plans etc. } \\
\square \text { Practical Content : } \\
\text { Participants divide into } \\
\text { groups of } 5 \text {. } \\
\text { MUST screening tool and } \\
\text { alternative anthropometric } \\
\text { measurements. } \\
\square \text { Case studies }\end{array}$ \\
\hline
\end{tabular}


Table 2: Mean knowledge scores for all health professionals for whom matched data were available at all three time points.

\begin{tabular}{|c|c|c|c|c|c|c|c|}
\hline \multirow[t]{2}{*}{$\begin{array}{l}\text { Health } \\
\text { Professional } \\
\text { Group }(n=52)\end{array}$} & $\begin{array}{l}\text { Score Pre- } \\
\text { Intervention }\end{array}$ & & $\begin{array}{l}\text { Score Post- } \\
\text { Intervention }\end{array}$ & & $\begin{array}{l}\text { Score } 6 \\
\text { Months Post- } \\
\text { Intervention } \\
\end{array}$ & & \\
\hline & Mean (SD) & $\begin{array}{c}\text { Mean } \\
\text { Rank } \\
*\end{array}$ & Mean (n*) & $\begin{array}{c}\text { Mean } \\
\text { Rank } \\
*\end{array}$ & Mean (SD) & $\begin{array}{c}\text { Mean } \\
\text { Rank } \\
*\end{array}$ & $\begin{array}{c}\mathbf{P} \\
\text { Value }\end{array}$ \\
\hline $\begin{array}{l}\text { General } \\
\text { Practitioner } \\
(n=10)\end{array}$ & $3.3(2.21)$ & 1.10 & $7.6(0.51)$ & 2.75 & $6.8(0.91)$ & 2.15 & $0.000 *$ \\
\hline $\begin{array}{l}\text { Practice Nurse } \\
(n=4)\end{array}$ & $3.0(2.16)$ & 1.25 & $7.0(0.81)$ & 2.63 & $6.25(0.95)$ & 2.13 & 0.092 \\
\hline $\begin{array}{l}\text { Community } \\
\text { Nurse }(n=32)\end{array}$ & $4.4(1.48)$ & 1.20 & $6.8(1.22)$ & 2.66 & $6.1(1.26)$ & 2.14 & $0.000 *$ \\
\hline $\begin{array}{l}\text { Nursing Home } \\
\text { Staff Nurse } \\
(n=6)\end{array}$ & $3.0(1.09)$ & 1.0 & $6.5(1.51)$ & 2.58 & $6.33(1.63)$ & 2.42 & $0.009 *$ \\
\hline Total Group & $3.9(1.73)$ & $1.16^{*}$ & $6.9(1.15)$ & $2.66 *$ & $6.2(1.2)$ & $2.17 *$ & $0.000 *$ \\
\hline
\end{tabular}

*Friedman Test Sig Level

Table 3: Health professional rating of the 'usefulness' of individual resources provided during the education intervention

\begin{tabular}{l|lllll}
\hline & $n^{*}$ & Min & Max & $\begin{array}{l}\text { Mean } \\
\text { Rating out } \\
\text { of 5 }\end{array}$ & Std. Dev \\
& & & & & \\
\hline Resource Folder & 53 & 2 & 5 & 4.1 & 1.10 \\
'MUST' & 53 & 2 & 5 & 4.5 & 0.72 \\
'Small Appetite' advice booklet & 54 & 2 & 5 & 4.4 & 0.92 \\
'A guide to using ONS' advice booklet & 53 & 1 & 5 & 4.2 & 1.14 \\
Adult weighing scales & 34 & 2 & 5 & 4.4 & 0.98 \\
Community dietitian referral form & 49 & 2 & 5 & 4.6 & 0.78 \\
\hline
\end{tabular}

$n^{*}=$ Number of health professionals who answered this question 
Table 4 : Use of 'MUST' (MAG, 2003) as reported by health professionals

\begin{tabular}{l|ccc}
\hline & \multicolumn{3}{|l}{ Have you used the MUST since the education } \\
& \multicolumn{2}{|l}{ Yntervention? } & \\
\hline & $\mathbf{n}(\%)$ & No & No response \\
\hline Health Professional Group & $5(83)$ & $1(7)$ & $\mathbf{n}(\%)$ \\
\hline Nursing Home Staff Nurse (n=6) & $23(68)$ & $10(29)$ & $1(3)$ \\
Community Nurse (n=34) & $5(50)$ & $5(50)$ & $0(0)$ \\
General Practitioner (n=10) & $2(40)$ & $3(60)$ & $0(0)$ \\
Practice Nurse (n=5) & $35(64)$ & $19(35)$ & $1(2)$ \\
\hline Total Group $(\mathbf{n}=55)$ & & & \\
\hline
\end{tabular}

Table 5: Health professional's responses to questions about specific practices related to ONS prescribing.

\begin{tabular}{|c|c|c|c|}
\hline$n=$ number of health professionals & \multicolumn{2}{|c|}{$n=$ number of health professionals } & Never \\
\hline $\begin{array}{l}\text { Do you give dietary advice to patients who } \\
\text { are at risk of malnutrition? }\end{array}$ & $\mathrm{n}(\%)$ & $\mathrm{n}(\%)$ & $\mathrm{n}(\%)$ \\
\hline General Practitioner $n=10$ & $7(\mathbf{7 0})$ & $1(\mathbf{1 0})$ & $2(20)$ \\
\hline Community Nurse $n=33$ & $28(\mathbf{8 5})$ & $5(15)$ & $0(\mathbf{0})$ \\
\hline Practice Nurse $n=5$ & $3(60)$ & $1(20)$ & $1(20)$ \\
\hline Staff Nurse $n=6$ & $5(83)$ & $1(17)$ & $0(\mathbf{0})$ \\
\hline Total Group $\mathrm{n}=54$ & $43(\mathbf{8 0})$ & $8(\mathbf{1 5})$ & $3(5)$ \\
\hline \multicolumn{4}{|l|}{$\begin{array}{l}\text { Do you give advice to patients on how ONS } \\
\text { should be used? }\end{array}$} \\
\hline General Practitioner $n=10$ & $7(\mathbf{7 0})$ & $1(\mathbf{1 0})$ & $2(20)$ \\
\hline$*$ Community Nurse $n=32$ & $15(47)$ & $9(28)$ & $8(25)$ \\
\hline Practice Nurse $n=5$ & $1(20)$ & $1(20)$ & $3(12)$ \\
\hline Staff Nurse $n=6$ & $2(33)$ & $0(\mathbf{0})$ & $4(66)$ \\
\hline Total Group $\mathrm{n}=53$ & $25(47)$ & $11(21)$ & $17(32)$ \\
\hline \multicolumn{4}{|l|}{$\begin{array}{l}\text { Do you specifically review the progress of } \\
\text { patients to whom you have prescribed ONS? }\end{array}$} \\
\hline General Practitioner $n=10$ & $6(60)$ & $2(20)$ & $2(20)$ \\
\hline Community Nurse $n=33$ & $19(\mathbf{5 8})$ & $8(24)$ & $6(18)$ \\
\hline Practice Nurse $n=5$ & $1(20)$ & $1(20)$ & $3(60)$ \\
\hline Staff Nurse $n=6$ & $4(66)$ & $0(\mathbf{0})$ & $2(33)$ \\
\hline
\end{tabular}


Table 6: Reported change in frequency of ONS prescribing reported by health professionals 6 months after the education programme .

\begin{tabular}{lccccc}
\hline & Decreased & Increased & No change & $\begin{array}{l}\text { Don't } \\
\text { know }\end{array}$ & No response \\
$\begin{array}{l}\mathrm{n}=\text { number of health } \\
\text { professionals }\end{array}$ & $\mathbf{n}(\%)$ & $\mathrm{n}(\%)$ & $\mathrm{n}(\%)$ & $\mathrm{n}(\%)$ \\
\hline $\begin{array}{l}\text { General Practitioner } \\
(\mathbf{n = 1 0})\end{array}$ & $\mathbf{7 ( 7 0 )}$ & 0 & 3 & 0 & 0 \\
$\begin{array}{l}\text { Practice Nurse (n=4) } \\
\text { Community Nurse( } \\
\mathbf{n = 3 5})\end{array}$ & $\mathbf{2 ( 5 0 )}$ & 0 & 0 & 2 & 0 \\
$\begin{array}{l}\text { Staff Nurse (n=6) } \\
\begin{array}{l}\text { Total Group } \\
(\mathbf{n = 5 5})\end{array}\end{array}$ & $\mathbf{1 7}(49)$ & $8(23)$ & $7(20)$ & $0(0)$ & $3(9)$ \\
\hline
\end{tabular}


Figure 1: Flowchart of study sequence.

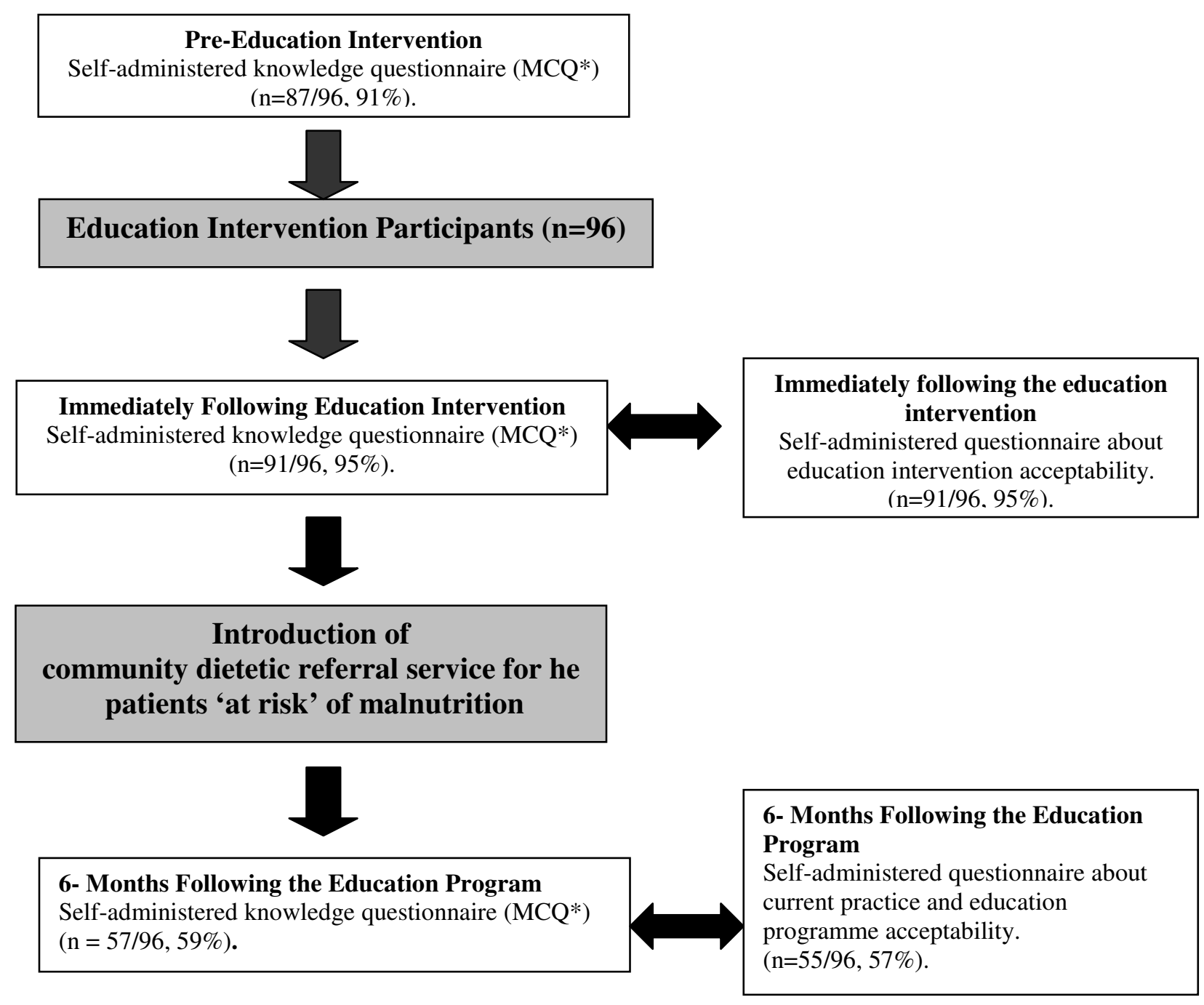

$\mathrm{MCQ}=$ multiple choice questionnaire $\mathrm{n}=$ number of health professionals 
Figure 2: Grouped responses of health professionals to the question: What did you find most useful about the training session? $(n=81 / 91)$

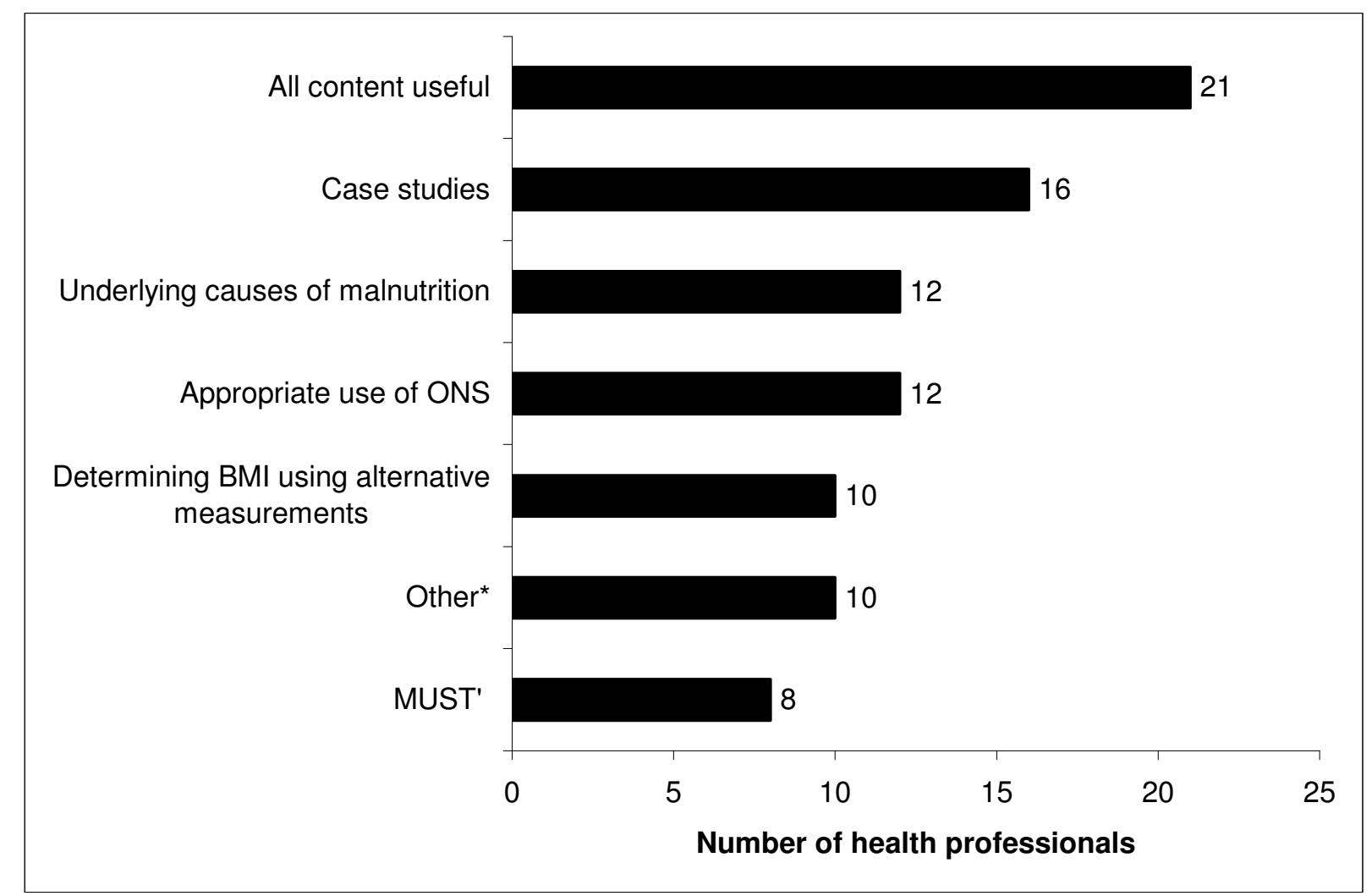

* Dietary Advice (n=4) Printed Resources (n=3), How to refer patients to the Community Dietitian (n=3). 
Fig 3: Health professional responses to question: 'What factors influence your decision to prescribe/recommend ONS ?

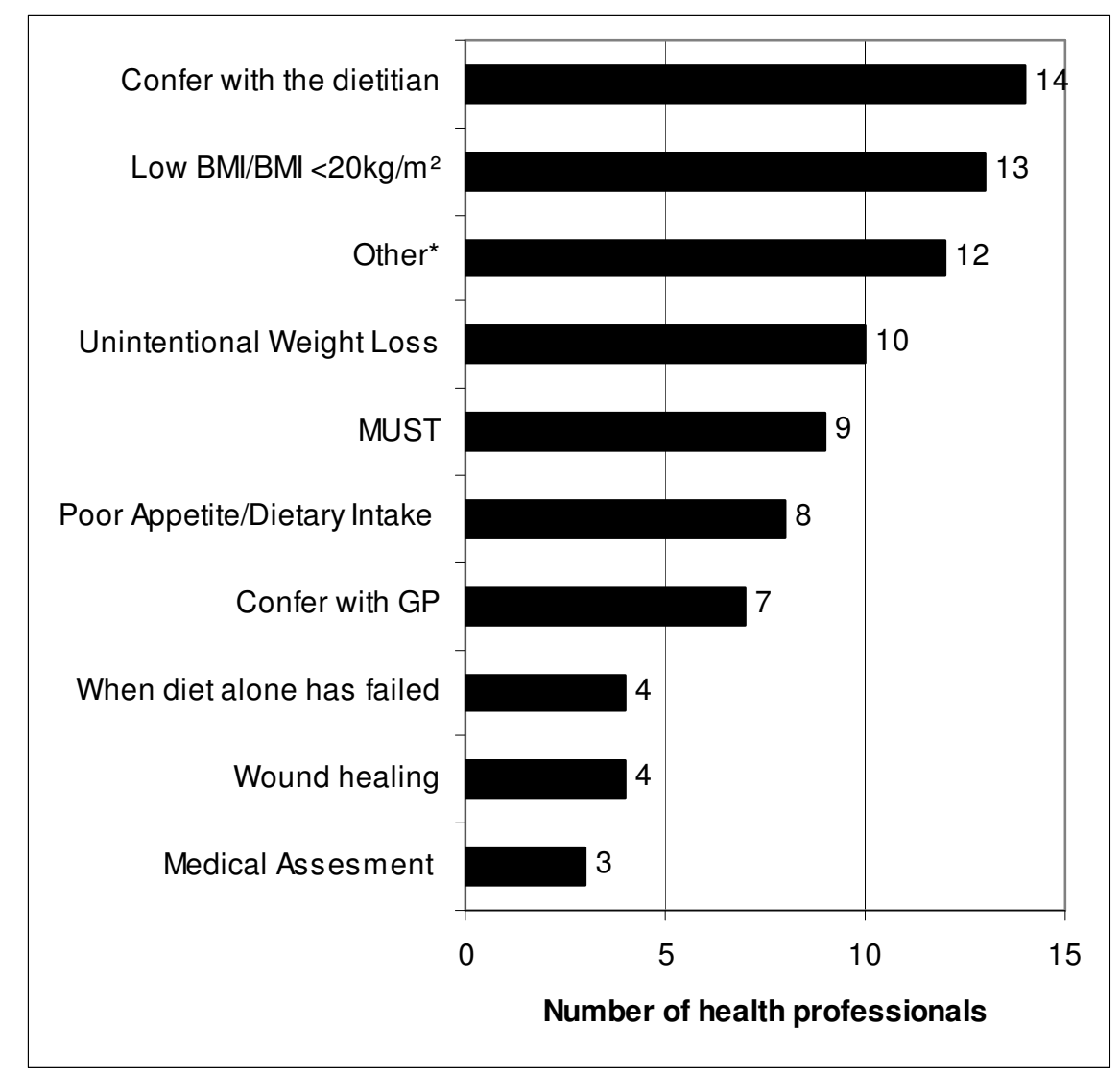

Other * Includes : Post Surgery ( $n=2)$, Poor Social Circumstances ( $n=2)$, Lack of Energy $(n=2)$, Measure weight ( $\mathrm{n}=1)$, Undernourished ( $\mathrm{n}=1)$, Reduced Dexterity (1), Assess Current diet ( $\mathrm{n}=1)$, When patient has met criteria $(\mathrm{n}=1)$, Palliative Care $(\mathrm{n}=1)$ 
Fig 4: Most common responses of health professionals to question: What type of dietary do you give to patients who are at risk of malnutrition?

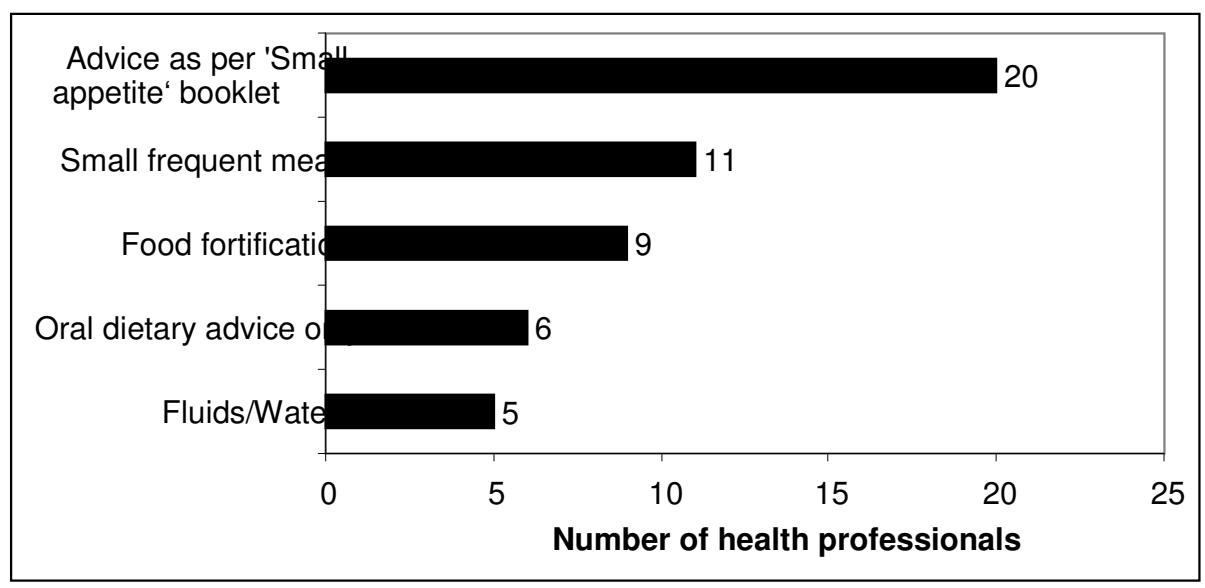


Figure 5: Barriers to giving dietary advice reported by health professionals six months after the education intervention.

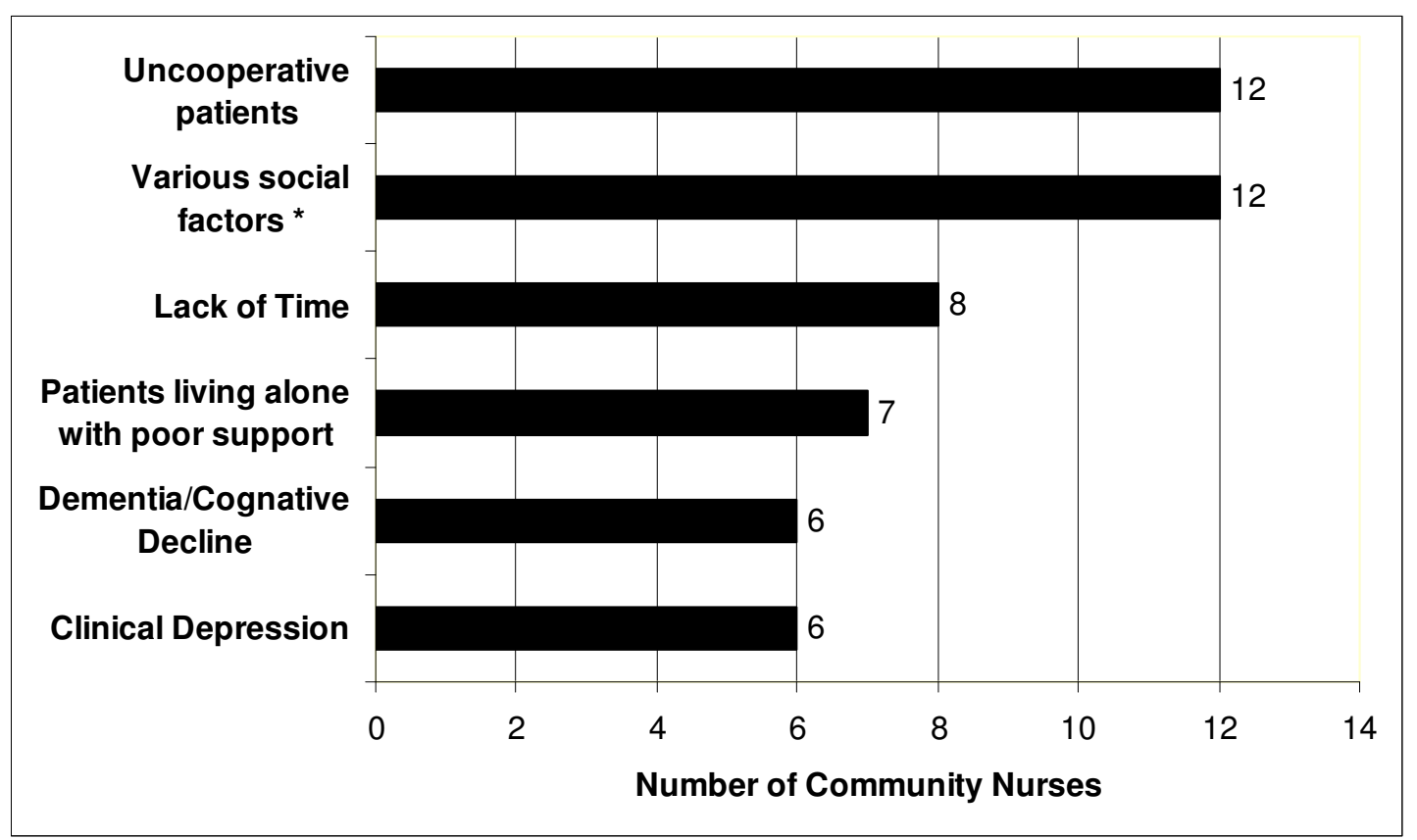

*Food preparation difficulties (n=2), Lack of family supports (n3), Poverty /Social Deprivation(n3) Unsuitable Cooking Facilities (n2), Literacy Levels (n1), Poor English(n1).

Other barriers reported by health professionals: Don't see relevant patients (n 3),Elderly (n3), , Lack of confidence (n1), Patient Attitudes(n2), Effects of Illness (n1), GPs unwilling to prescribe ONS (n1), Hearing Impairment(n1) Mobility Problems (n1), Aggressive patients (n1), Poor patient understanding $(\mathrm{n} 1)$ 
Fig 6: Most common responses to question: How do you review the progress of patients prescribed ONS?

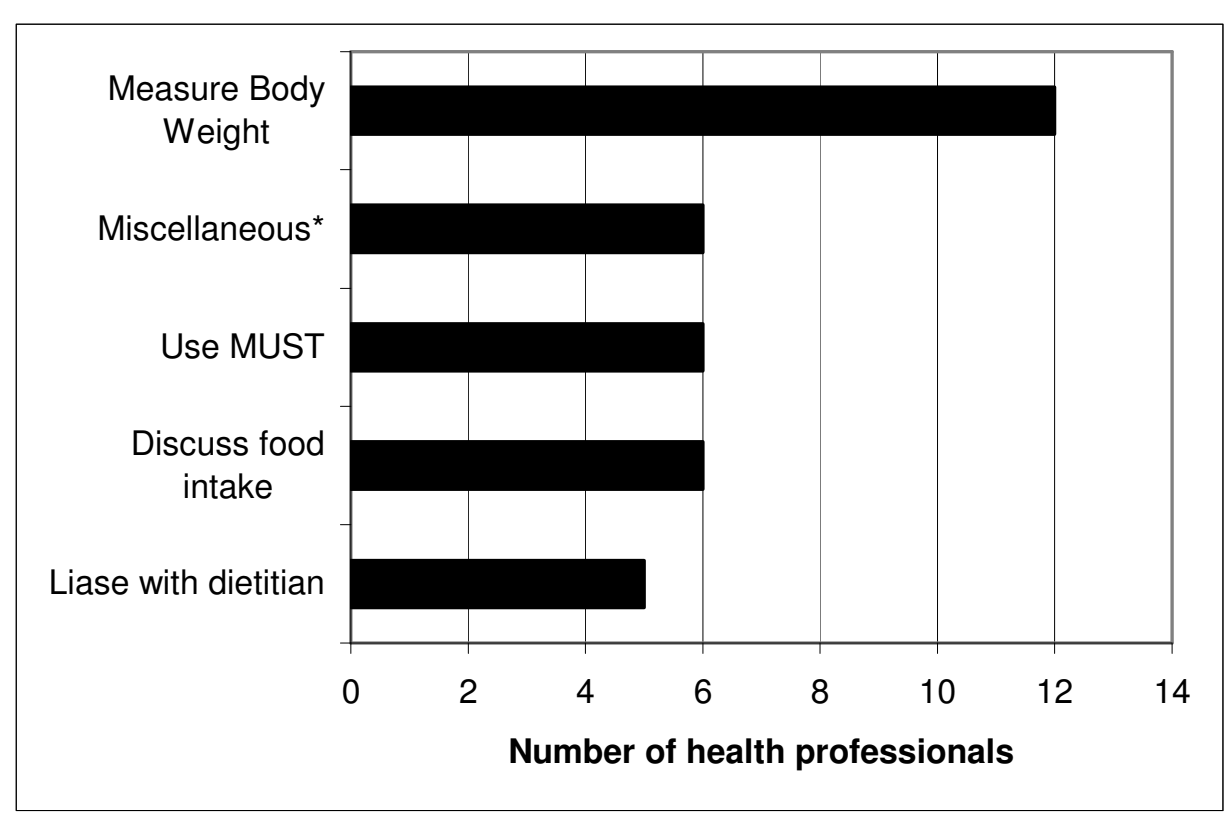

* Energy levels (n1), Check wound healing (n=1), Clinical Condition (n=1), Lease with GP (n=1), 'In monthly reports' (n=1), MUAC $(n=1)$ 


\section{References}

BARRY, M. (2009) Economies in drug usage in the Irish healthcare setting. National Centre for Pharmacoeconomics. Department of Health and Children. Available at http://www.dohc.ie/publications/economies drug usage.html.Accessed January 2010.

BROWNE, J. P., O'DOHERTY, V. A., MCGEE, H. M., MCLAUGHLIN, B., O'BOYLE, C. A. \& FULLER, R. (1997) General practitioner and public health nurse views of nutritional risk factors in the elderly. Ir J Med Sci, 166, 23-5.

CADMAN, L. \& FINDLAY, A. (1998) Assessing practice nurses' change in nutrition knowledge following training from a primary care dietitian. $J R$ Soc Promot Health, 118, 206-9.

CROGAN, N. L., SHULTZ, J. A. \& MASSEY, L. K. (2001) Nutrition knowledge of nurses in long-term care facilities. J Contin Educ Nurs, 32, 171-6.

CSO (2006) Persons, males and females in each province, county, and city classified by age group, 2006. www.cso.ie, Central Statistics Office Ireland.(Accessed May 2008).

GALE, C. R., EDINGTON, J., COLES, S. J. \& MARTYN, C. N. (2001) Patterns of prescribing of nutritional supplements in the United Kingdom. Clin Nutr, 20, 333-7.

GALL, M. J., HARMER, J. E. \& WANSTALL, H. J. (2001) Prescribing of oral nutritional supplements in Primary Care: can guidelines supported by education improve prescribing practice? Clin Nutr, 20, 511-5.

GHOSH, A. K. (2008) Organizing an effective continuous medical education session. J Assoc Physicians India, 56, 533-8.

HIDDINK, G. J., HAUTVAST, J. G., VAN WOERKUM, C. M., VAN'T HOF, M. A. \& FIEREN, C. J. (1999) Cross-sectional and longitudinal analyses of nutrition guidance by primary care physicians. Eur J Clin Nutr, 53 Suppl 2, S35-43.

KENNELLY, S., KENNEDY, N. P., RUGHOOBUR, G. F., SLATTERY, C. G. \& SUGRUE, S. (2009) The use of oral nutritional supplements in an Irish community setting. September ,4.Journal of Human Nutrition and Dietetics.[Published online ahead of print].

KUSHNER, R. F. (1995) Barriers to providing nutrition counselling by physicians: a survey of primary care practitioners. Prev Med, 24, 546-52.

LEE, R. \& SCOTT, F. (2009) Competent to care. A train-the-trainer method of teaching as a way of implementing the correct use of the 'Malnutrition Universal Screening Tool' in Norfolk: is it effective? Proc Nutr Soc, 68, 300-5.

LOANE, D., FLANAGAN, G., SIUN, A., MCNAMARA, E. \& KENNY, S. (2004) Nutrition in the community--an exploratory study of oral nutritional supplements in a health board area in Ireland. J Hum Nutr Diet, 17, 257-66.

MADIGAN, S. (2005) The development, delivery and evaluation of a pragmatic nutrition education intervention for primary healthcare professionals. Chapter 2 :Educational outreach in small groups with healthcare professionals a review of the literature. $P h D$ Thesis. Institute of post graduate medicine and primary care, faculty of life and health sciences, University of Ulster.

MAG (2003) The 'MUST' report. ELIA, M. (Ed). Worcs, British Association for Enteral and Parenteral Nutrition.

MCCOMBIE, L. (1999) Sip feed prescribing in primary care:an audit of current practice in Greater Glasgow Healthboard,Glasgow, UK. Journal of Human Nutrition and Dietetics, 12, 201-202. 
MIDLOV, P., BONDESSON, A., ERIKSSON, T., NERBRAND, C. \& HOGLUND, P. (2006) Effects of educational outreach visits on prescribing of benzodiazepines and antipsychotic drugs to elderly patients in primary health care in southern Sweden. Fam Pract, 23, 60-4.

Milne, A.C., J. Potter, and A. Avenell, Protein and energy supplementation in elderly people at risk from malnutrition. Cochrane Database Syst Rev, 2005(2): p. CD003288.

MOORE, H. \& ADAMSON, A. J. (2002) Nutrition interventions by primary care staff: a survey of involvement, knowledge and attitude. Public Health Nutr, 5, 531-6.

NICE (2006) Nutrition support in adults: oral nutritional support, enteral tube feeding, and parenteral nutrition. London, National Institute for Health and Clinical Excellence.

O'BRIEN, M. A., ROGERS, S., JAMTVEDT, G., OXMAN, A. D., ODGAARD-JENSEN, J., KRISTOFFERSEN, D. T., FORSETLUND, L., BAINBRIDGE, D., FREEMANTLE, N., DAVIS, D. A., HAYNES, R. B. \& HARVEY, E. L. (2007) Educational outreach visits: effects on professional practice and health care outcomes. Cochrane Database Syst Rev, CD000409.

STANEK, K., POWELL, C. \& BETTS, N. (1991) Nutritional knowledge of nurses in long-term health care facilities. $J$ Nutr Elder, 10, 35-48.

STRATTON, R. J. \& ELIA, M. (2000) Are oral nutritional supplements of benefit to patients in the community? Findings from a systematic review. Curr Opin Clin Nutr Metab Care, 3, 311-5.

STRATTON, R. J., HACKSTON, A., LONGMORE, D., DIXON, R., PRICE, S., STROUD, M., KING, C. \& ELIA, M. (2004) Malnutrition in hospital outpatients and inpatients: prevalence, concurrent validity and ease of use of the 'malnutrition universal screening tool' ('MUST') for adults. Br J Nutr, 92, 799-808.

VOLKERT, D., BERNER, Y. N., BERRY, E., CEDERHOLM, T., COTI BERTRAND, P., MILNE, A., PALMBLAD, J., SCHNEIDER, S., SOBOTKA, L., STANGA, Z., LENZENGROSSIMLINGHAUS, R., KRYS, U., PIRLICH, M., HERBST, B., SCHUTZ, T., SCHROER, W., WEINREBE, W., OCKENGA, J. \& LOCHS, H. (2006) ESPEN Guidelines on Enteral Nutrition: Geriatrics. Clin Nutr, 25, 330-60.

WELSCHEN, I., KUYVENHOVEN, M. M., HOES, A. W. \& VERHEIJ, T. J. (2004) Effectiveness of a multiple intervention to reduce antibiotic prescribing for respiratory tract symptoms in primary care: randomised controlled trial. BMJ, 329, 431. 